\title{
Growing Musicians in English secondary schools at Key Stage 3 (age 11-14)
}

\begin{abstract}
The National Curriculum for Music in England at Key Stage 3 (KS3; age 11-14) declares its purpose that pupils should be inspired to "develop a love of music and their talent as musicians" (DfE, 2013: KS3 Music). The Office for Standards in Education (Ofsted) have criticised secondary schools for a lack of progress in the musical development of pupils (e.g. Ofsted, 2009; 2012). This paper reports on an exploratory study into how far class music lessons at KS3 provide for the development of the musician and the relationship between the musical values of music teachers and classroom practice. The research centres on an investigation into the place of musical competencies in music learning and the contexts within which musicianship can develop. It concludes that classroom music lessons have a tendency to focus more on presenting pupils with a range of 'taster' musical experiences than in the development of musicians.
\end{abstract}

Key words

Musicianship Education Competencies Secondary

\section{Introduction: Defining the musician}

Defining a 'musician' is not a straightforward task. To some, a musician is one who plays a musical instrument or sings (Ben-Tovim, 1979; Fletcher, 1989). To others, being a musician suggests a more 'formally trained' approach to participation, probably through study, tuition and consistent practise - en route to possibly becoming a professional (McPherson et al., 2012). A further view is that being a musician is wider than simply being a performer; that they will also be involved in devising music (composing, improvising) and active listening when, for example, extending one's knowledge and experience of music through attendance at live events (Pflederer, 1963; Paynter, 1994; Müllensiefen et al., 2011). Yet another view is one which purports that we all, as human beings, are 'hard-wired' for music and that, as such, we are all musicians whenever we engage with the art form in any way and at whatever level of competence (Welch, 2001; Mills, 2005; Cross, 2006). The first two of the these definitions would suggest that a young child who is clapping along to a music recording of a favourite song is not, strictly speaking, a musician; they are simply demonstrating some musicality. However, the 
last of the definitions would suggest a contradiction: that this young child is a musician, a view corroborated by Jaffurs (2004):

"some educators believe that musicality is manifested in the technical achievements of musicians. Others believe that technique is secondary and musiciality is the level of expression a musician is able to bring to their work." (Jaffurs, 2004: 3)

This paper takes the ontological position that being musical - a reference to potential (adjective) and engagement (noun) - is a 'stepping stone' to becoming a musician. If everyone has the capacity to be musical, it is arguably through participation, education, training, practise and progression that one attains the goal of becoming a musician (Kemp, 1996). This line of thinking would suggest that we all have musical potential (Mills, 2005) but we are at different points along the 'road', and our progression along the road depends very much on the support we receive from those around us and the opportunities for 'training' in the musical skills and knowledge we are presented with (Welch, 2012). How we might recognise that we have actually reached the point where we might confidently define ourselves as musicians is difficult to determine. However, to set young people on that road towards attaining musicianship is, surely, one of the principle goals of school music teaching (DfE, 2011; 2013).

Whilst it might be argued that everyone has the capacity to be musical, there are likely to be specific characteristics which will identify a person as possessing more developed musical potential. One's level of musicality may depend, for example, on ability to perform (instrumentally and/or vocally), to devise one's own music, to listen in a focused and active manner to live and recorded music, and be open to a range of different music (Hargreaves, 1986; Hallam, 2011). Indeed, musicians may well be 'operating' in many or all of these activities at one and the same time (Clarke et al., 2010). Listening, though, is the allpervasive musical activity and can be observed when anyone listens to recorded and live music, but also when appraising one's own performance or composition, making adjustments in the light of what is heard (Cooke et al., 2016).

\section{Musicianship in the secondary school at KS3 (11-14)}

The purpose of the National Curriculum Framework in England (NC) (DfE, 2013) is that those who engage with music are frequently involved in the integration of musical activities and it argues that "a high quality music education should engage and inspire pupils to develop a love of music and their talent as musicians..." (DfE, 2013: KS3 Music). Notable is the use of the word 'musician' and the implication that all young people are, or can be, musicians; further, that the Subject Content (ibid.) is designed with the intention to seek to develop musicians. Mills (2005) puts the even more forthright view that "we teach music in school primarily because we want children - all children - to grow as musicians... music is not a gift but a right" (Mills, 2005: 5). Despite this, however, music has been demonstrated to be problematic 
in schools (Saunders, 2008; Welch et al., 2010; Spruce \& Matthews, 2012). There are young people for whom secondary music education does not meet their needs. The more musically orientated find it necessary to also participate in a range of additional in and out-of-school activities (e.g. instrument lessons) (Wright, 2012), whilst the less musically orientated do not seem to make significant progress (Ofsted, 2012) and find that much of the music presented to them is not representative of their musical interests and needs (Saunders \& Welch, 2012; Wright 2012). Hallam (2006) suggests that taking on the identity of a musician requires a commitment to music which derives from motivation, self-efficacy and some ownership of the musical repertoire and peer-groupings in which they participate, yet it has also been argued (Savage, 2013) that the school curriculum tends to be based on the 'delivery model' in which "teachers are the white-van curriculum delivery service, dropping off pre-ordained packages of curriculum content within a set timetable of deliveries" (p.85).

Saunders and Welch (2012) argue that young people access music-making and develop as musicians in a variety of ways: (a) formal education in the school classroom, (b) the school's extra-curricular programmes, (c) instrumental/vocal specialist teaching, and (d) from within their communities, e.g. local music groups and peer-to-peer music making. The more committed musicians will frequently participate in many/all of these learning contexts (Wright, 2012), though classroom music can be the least useful in meeting personal developmental needs (ibid.; Saunders, 2008; Spruce \& Matthews, 2012). This may be because they see the classroom experience as lacking authenticity: that it does not match their aspirations or expectations of the musician they wish to be and those they observe in out-of-school contexts (Bibby, 2013). It is common for those students participating in music-making outside of formal education to tend to be the most motivated to grow as musicians: "it was those pupils involved in the 'extended' curriculum that were most likely to opt to study music at GCSE level" (Bray, 2000 in Saunders, 2008). The uptake at GCSE is one of the weakest for any subject area at around 7-8\% of the total annual cohort (Bray, 2000; Welch, 2012). Such data would suggest that, for the remaining 93\% of students, many of whom do not participate in the extended curriculum, music at KS3 is not fulfilling its purpose of seeking to develop young musicians (Welch, 2012).

The inevitable result of the issues described here is that some young people, particularly the more musically able wishing to seriously grow as musicians, will frequently need to supplement (even replace) what they are offered in school with a range of additional activities and learning, such as community music-making and instrumental/vocal tuition (Wright, 2012). This may reinforce the social stratification which Wright (2012) suggests is all-too-common in music education:

"as the ability to 'pay to play' in terms of access to additional instrumental and theory tuition outside school has long affected the nature of the student group able to elect for GCSE and BTEC/A level and other 16+ examinations in music... Those from more affluent families have preferential 
access to music as a curriculum subject once additional tuition becomes necessary" (Wright 2012: 30).

Furthermore and as stated above, there can be issues with the authenticity of the musical experience received by young people in school, in that activities may be 'divorced' from the 'real world' of the professional musician (Green, 2002; 2008; Bibby, 2013). Teachers, themselves, are largely educated in the Western classical tradition (York, 2001; Rogers, 2002) and can tend towards less secure knowledge and expertise in other genres and traditions (Saunders \& Welch, 2012).

It is principally how far some of the characteristics of a musician are developed in secondary school classroom music lessons, and the nature of the learning experience, which is at the centre of the research study described in this paper. There have been studies which have sought to examine student perceptions of their own musicianship (e.g. Saunders, 2008) and some on the role of teacher identity and biography in shaping music teaching and learning (e.g. Welch et al., 2010; Dalladay, 2014), but less on the way in which teaching and learning seeks to develop young musicians. This current study is limited by its size and its exploratory nature, and the fact that it has not consulted the young people themselves, but it seeks to examine some of the issues surrounding the development of musicianship within classroom music and to provide a potential stimulus to further research into this area.

\section{The learning contexts and competencies of musicians}

There would seem to be an overwhelming consensus in research, literature and the view of society that the ability to play a musical instrument is key to being a musician (e.g. Rogers, 2002; Hargreaves et al., 2002; Lamont, 2002; Hallam, 2006; Müllensiefen, 2011). In a survey into the work, education and training of professional musicians by Youth Music (Rogers, 2002), 84\% of the respondents had the musical skill of 'player' - by far the most cited skill/role of musicians completing the survey, with the next highest response being 50\% as 'tutor'. Young people themselves also believe that playing an instrument is important to being a musician: $21 \%$ of boys and $26 \%$ of girls reported that they were having instrument lessons at school (Hargreaves et al., 2002). Singing, too, is considered to be an important skill in music (Mills, 2005; Welch, 2006) and, additionally, might be regarded as more 'inclusive' than learning to play a musical instrument (Bannan, 2002). Whilst there are other characteristics of a musician, as discussed in the introduction to this paper (for example, as a composer), the literature points to the common perception that being a musician means that one can perform (Lamont, 2002; Müllensiefen, 2011).

Drawing on literature and research by various writers already discussed in this paper and others, it is possible to design a working set of competencies required of the musician; though it is likely that only the 
most full-formed musician will possess all or most and, therefore, that the developing musician will be exhibiting signs of increasing competence in a selection of them. These competencies (below) have derived and been compiled from both a study of relevant literature and debate with trainee teachers on a Post-Graduate Certificate in Education (PGCE) programme at an English initial teacher education (ITE) provider (Dalladay, 2014). They will become the focus of this research study. They are presented in no particular sequence.

Twelve competencies which can be associated with musicians:

i. The ability to perform on a musical instrument with confidence and appropriate technique;

ii. The ability to develop original, imaginative compositions;

iii. The ability to improvise with confidence;

iv. The ability to use musical terminology in appraising music;

v. The ability to read from staff notation fluently;

vi. The ability to sing with accurate intonation;

vii. The ability to use ICT to develop and enhance musical 'events';

viii. The ability to perform music 'by ear';

ix. The ability to harmonise melodies applying stylistic conventions;

x. A general knowledge of a range of music from different times, traditions and cultures;

xi. The ability to discuss, write and/or draw about the expressive content of music;

xii. The ability to aurally analyse the relationship between sounds (aural discrimination).

In like manner, it is also possible to draw up a list of the contexts in which musical development would seem to take place.

Twelve contexts from/in which musicianship can develop:

i. From a teacher (class and/or instrument);

ii. Through performing with others;

iii. From considering role models and musicians we admire;

iv. From family and/or friends;

v. Through regular practice;

vi. By being a teacher to others;

vii. Through developing our own musical ideas / composing;

viii. Through attending live musical performance (such as of peers, at concerts/gigs, etc.);

ix. Through academic studies (gaining qualifications);

x. Through listening to recorded music;

xi. Through performing to an audience;

xii. Through jamming / improvising / developing musical ideas with others 'by ear'. 


\section{Research design}

The two 'sets' of statements above - musical competencies and learning contexts - form the basis for the research described in this paper. Originally each set consisted of 10 statements and, through further discussion, reading and piloting, they were expanded to the 12 for each set listed above.

In phase 1 of the research, participants ranked the statements according to which, in their view, was most important (ranked in $1^{\text {st }}$ position) to the least $\left(12^{\text {th }}\right)$ for each of the two sets. The mean total data set for each of these two sorting activities (as they became known) was calculated and ranked. The research sample consisted of 39 participants, made up of 29 secondary school music teacher trainees and 10 experienced music teachers from secondary schools in partnership with the training provider.

In phase 2, a selection of 11 participants (6 trainees and 5 teachers) from those who had responded to the sorting activities were observed teaching one music lesson each and 10 of these (5 trainees and 5 teachers) were interviewed afterwards (phase 3 of the research). This group is termed the Core Participant Group (CPG). Written notes from the observations were made on a specially designed observation schedule detailing teacher activity, pupil activity and outcomes, and focusing on anything observed which related to the 12 musical competencies and 12 learning contexts. Also on this schedule, a time-line was plotted over the course of the lesson 'measuring' the time spent focusing on any of the musical competencies and learning contexts. Each of these were 'scored' (termed the 'Observed Significance Score' (OSS)) from 1-3 according to the following criteria:

1. Evident in the lesson, but not a major feature; for example, the activity is short and/or cursory;

2. Evident in the lesson with a degree of significance, but the competency/context is not fully observed; for example, pupils sing but with little accuracy of intonation or emphasis on its improvement;

3. The musical competency/context is strongly evident.

A mean of the OSSs was calculated and these, in turn, were ranked so that comparison with the sorting activity data could be made.

The semi-structured interviews that made up phase 3 of the research covered the same themes with each participant and included similar questions for discussion (Bryman, 2012). They were audio recorded, with the participants' permission, and then a 'semi-transcript' made (not a full word-by-word transcript) with timecoding so that, where necessary, it was straightforward to reference back to the recording for the precise wording. These themes have included memories of early musical beginnings, music education, developing interests in teaching, important competencies in the development of musicians, and so on. 
Some investigation of what had been noted in the lesson observation was also part of the interview, such as why a particular approach had been taken.

Supplementing the data from the sorting activities, observations and interviews was a survey (phase 4 of the research) conducted with 64 participants across a range of teachers, trainees and undergraduate music students across five Higher Education Institutions. The survey consisted of 60 statements, with a 7-point Likert scale for responses ( $1=\mathrm{I}$ don't agree; 7= I do agree), covering 6 themes: 'my own musical education', 'perceptions of one’s own musicianship', 'my musical influences', 'my musical activities', 'my views on musicality/musicianship', and 'my views on music education'. The survey facilitated a consideration of the views from a wider population sample on education, values and beliefs.

\section{Findings: Learning contexts}

Participants $(n=39)$ ranked the twelve statements detailed above into order of significance in response to the question, “what people or activities contributed most to your own development as a musician?" Table 1 shows the mean ranking across the participant group.

\begin{tabular}{|l|l|l|l|}
\hline Position & $\begin{array}{l}\text { Mean } \\
\text { Rank }\end{array}$ & Music Learning Context & n \\
\hline $\mathbf{1}$ & 4.28 & Performing with others & 39 \\
\hline $\mathbf{2}$ & 4.36 & Regular music practice & 39 \\
\hline $\mathbf{3}$ & 4.38 & A teacher (classroom or instrument) & 39 \\
\hline $\mathbf{4}$ & 5.31 & Listening to recorded music & 39 \\
\hline $\mathbf{5}$ & 5.54 & Role models / musicians I admire & 39 \\
\hline $\mathbf{6}$ & 5.59 & Family and/or friends & 39 \\
\hline $\mathbf{7}$ & 5.67 & Performing to a live audience & 27 \\
\hline $\mathbf{8}$ & 5.92 & Attending live musical performances & 39 \\
\hline $\mathbf{9}$ & 7.03 & Being a teacher to others & 38 \\
\hline $\mathbf{1 0}$ & 7.12 & Jamming / Improvising & 38 \\
\hline $\mathbf{1 1}$ & 7.18 & Composing & 26 \\
\hline $\mathbf{1 2}$ & 7.87 & Academic musical studies & 39 \\
\hline
\end{tabular}

Table 1

Sorting activity: musical learning contexts. Mean rankings of the total participant group (1 high, 12 low) $\mathrm{n}=39$ participants with some variation noted in the final column

There will be little surprise to many musicians concerning the placing of 'performing with others' and 'regular music practice' in the top two positions (Table 1) as they will frequently make music with fellow musicians in orchestras, bands, choirs, and so on (Hallam, 2011) and, in order to gain some proficiency, will devote many hours of practice (Lehmann \& Gruber, 2006; McPherson et al., 2012). In interview, several participants commented on the significance of rehearsing and performing music with others; for example, one discussed the importance of developing musically within the brass-band tradition, and another stated that he continues to perform in an ensemble for events such as weddings at weekends. 
It is also noted in these data (Table 1) that teachers are perceived as significant in influencing the development of musicians. However, it is, perhaps, more surprising that 'family and friends' are comparatively low, in $6^{\text {th }}$ position, despite the literature in general pointing towards the positive influence of these (e.g. Harrison \& McCullough, 2011; Borthwick \& Davidson, 2012; McPherson et al., 2012). In interviews with the CPG, too, the responses suggest a strong influence from family with many family members also being musicians (in 7 of the 10). In the survey ( $n=64) 41.2 \%$ indicated that they had at least one musical parent and $68.8 \%$, a musical sibling. However, $77.8 \%$ indicated that they 'grew up in a musical home'.

A desire to compose would seem to be less significant in the development of musicianship. Composing was ranked in $11^{\text {th }}$ position (Table 1 ) and jamming/improvising in $10^{\text {th }}$; and, in the survey, $58.8 \%$ claimed to have composed music for public use. Hargreaves suggests that musicians frequently work "on the run", not only as performers but also as composers (Hargreaves, 1986: 148). Paynter (1982) supports the view that devising music is central to developing musicianship and an understanding of how music 'works'. Devising work frequently plays a significant part in school music lessons (5 out of the 11 lessons observed as part of this study included composing and/or improvising) and it is a central part of the National Curriculum (DfE, 2013) but teachers seem to be a little at a loss as to how to guide pupils in the task - the survey suggesting that a little over half the respondents have any experience in the activity $(58.8 \%)$.

\section{Findings: Musical competencies}

Once again, participants ranked the twelve statements relating to musical competencies into order of perceived significance in response to the question, "in your view, what competencies are the most important in developing musicianship". Table 2 shows the mean ranking across the whole of the participant group.

\begin{tabular}{|l|l|l|l|}
\hline Position & $\begin{array}{l}\text { Mean } \\
\text { Rank }\end{array}$ & Musical competency & $\mathrm{n}$ \\
\hline $\mathbf{1}$ & 3.21 & Performing on an instrument & 39 \\
\hline $\mathbf{2}$ & 3.97 & Performing 'by ear' & 39 \\
\hline $\mathbf{3}$ & 4.23 & Singing with accurate intonation & 27 \\
\hline $\mathbf{4}$ & 4.52 & Aural analysis between sounds & 39 \\
\hline $\mathbf{5}$ & 4.67 & Composing & 39 \\
\hline $\mathbf{6}$ & 5.05 & Improvising & 39 \\
\hline $\mathbf{7}$ & 5.69 & General knowledge of range of musics & 39 \\
\hline $\mathbf{8}$ & 6.15 & Relate to the expressive content & 27 \\
\hline $\mathbf{9}$ & 6.67 & Reading from staff notation & 39 \\
\hline $\mathbf{1 0}$ & 7.46 & Use of musical terminology & 39 \\
\hline $\mathbf{1 1}$ & 8.03 & Harmonization of melodies & 39 \\
\hline $\mathbf{1 2}$ & 8.10 & Use of ICT to develop music & 39 \\
\hline
\end{tabular}


Performing on an instrument, as suggested by the literature discussed earlier, ranks highest as the chief indicator of, and competency required for, the musician. What is possibly more contentious surrounds the competencies of performing by ear and from notation. Whilst 'performing music by ear' (being able to hear music and perform it based on that hearing, rather than being reliant on reading from notation) is a skill of aural perception, for the purposes of this study, it has been separated from 'aural analysis' as a dinstinct skill particularly valued by some, such as popular musicians (Green, 2002). In the survey $(\mathrm{n}=64), 55 \%$ considered that musicians should possess this skill. However, the competency was placed high $\left(2^{\text {nd }}\right.$ position) in the sorting activity. It is noted that Western Classical Musicians (WCM) considered this to be significantly less important than those from the Other-than-Classical Musicians (OCM) ${ }^{1}$ or mixed $(33 \%: 63 \%)$. The possible reason for this is that WCMs tend to prioritise notation-based and analytical skills whilst OCMs place greater emphasis on memorisation and improvisation (Hargreaves et al., 2002; Welch et al., 2008). With reference to notation skills, a minority of respondents (15\%) consider this to be a particularly important competency for musicians though this does contrast with the much higher $56.3 \%$ of the survey respondents who believe that secondary school students should be taught how to read music.

During interviews it became clear that the CPG generally supported the view of the pre-eminence of an ability to be able to perform on a musical instrument in order to grow as a musician, though one participant did respond that it was his view that it is possible to be a 'fantastic musician and not play a note' - as in employing the use of ICT, for example. The ability to be able to perform by ear was not, however, raised in interviews, though just 3 of the 10 members of the CPG were principally trained in genres other than the Western classical tradition which would have involved some extensive use of playing by ear (e.g. in traditional and contemporary popular genres).

Composing, which appears as both a learning context and a musical competency, seems to offer an interesting contrast in the results of the sorting activities. In general, it was considered a fairly important musical competency ( $5^{\text {th }}$ in ranking, with improvising - a form of more spontaneous composing - at $\left.6^{\text {th }}\right)$, whilst as a context for developing musicianship it was ranked much lower as detailed in the previous section of this paper. Whist there seems to be some acknowledgement that being involved in devising original music is important for musicians, several have not either participated in the activity much in

\footnotetext{
${ }^{1}$ Participants, as part of their demographic details, were asked about their main and preferred musical performance genre. This grouping of musicians as 'Western Classical Musicians' and 'Other-than-Classical Musicians' derives from the Teaching and Learning Research Programme (TLRP) data of Welch (2008; 2012); ref. http://www.tlrp.org/proj/Welch.html. In these groupings, OCMs include popular, jazz, musical theatre, world and mixed genres. The differential between Western classical music and the 'otherness' of other musics has also been a highlighted issue in education in some other texts, e.g. Spruce \& Matthews (2012).
} 
developing their own musicianship or have had few opportunities to develop the skill (a little over half of the survey respondents, as mentioned above).

\section{Ideology and practice}

In comparing the values of the research participants of what they felt were important contextual and experiential factors in the development of musicians (Tables 1 and 2) with what is covered in the classroom, there are some differences of emphasis (Table 3).

\begin{tabular}{|l|l|l|l|l|l|}
\hline Musical competences & $\begin{array}{l}\text { OSS } \\
\text { mean } \\
\text { rank }\end{array}$ & $\begin{array}{l}\text { Sorting } \\
\text { Activity } \\
\text { mean } \\
\text { rank }\end{array}$ & Learning contexts & $\begin{array}{l}\text { OSS } \\
\text { mean } \\
\text { rank }\end{array}$ & $\begin{array}{l}\text { Sorting } \\
\text { Activity } \\
\text { mean } \\
\text { rank }\end{array}$ \\
\hline Performing on an instrument & 1 & 1 & A teacher (class or instrument) & 1 & 3 \\
\hline Composing & 6 & 5 & Performing with others & 2 & 1 \\
\hline Improvising & 9 & 6 & Role models / musicians I admire & 3 & 5 \\
\hline Use of musical terminology & 5 & 10 & Family and/or friends & 4 & 6 \\
\hline Reading from staff notation & 9 & 9 & Regular music practice & 7 & 2 \\
\hline Singing with accurate intonation & 7 & 3 & Being a teacher to others & 11 & 9 \\
\hline Use of ICT to develop music & 4 & 12 & Composing & 10 & 11 \\
\hline Performing music 'by ear' & 2 & 2 & Attending live musical perfs. & 8 & 8 \\
\hline Harmonization of melodies & 12 & 11 & Academic musical studies & 8 & 12 \\
\hline General knowledge of range of musics & 3 & 7 & Listening to recorded music & 5 & 4 \\
\hline Relate to the expressive content & 11 & 8 & Performing to an audience & 5 & 7 \\
\hline Aural analysis between sounds & 7 & 4 & Jamming / improvising & 11 & 10 \\
\hline
\end{tabular}

Table 3

A comparison of the perceived importance of musical competencies and learning contexts with observed significance scores (OSS) in class music lessons. In the rankings, $1=$ high, $12=$ low.

In relation to the 'Learning Contexts' data, 'regular music practice' is considered to be important in the development of musicianship but it appears to be less evident in the classroom. This may be a case of insufficient time available to allow the students the opportunity to re-visit tasks on a frequent basis. It is the case that just one lesson was observed of each participant but Ofsted (2012) supports this view in finding that time and timetabling for music had become an issue in many secondary schools. Data collected across all the observed lessons in the current study suggest that, on average, $57 \%$ of the time available was devoted to the development of any one or more of the musical competencies with the rest of the time being largely taken up with classroom and school routines (e.g. setting and reviewing targets, considering the learning objectives for the lesson, class management). Another aspect of the learning contexts in which there is a significant difference between perceived value and classroom practice is in 'academic musical studies' (e.g. learning about music), moving upwards from $12^{\text {th }}$ position in the sorting activity to $8^{\text {th }}$ position noted in the observations of teaching.

In respect of 'Musical Competencies', it is notable that the relative importance of musical terminology, having a general knowledge of a range of music and, most strikingly, the use of ICT (Information and Communication Technology), seem to take on more significance in practice than in the values of the 
teachers. In the case of the use of ICT to develop and enhance music-making, the sorting activity data suggests that most participants consider it to be rather low in importance (ranked in $12^{\text {th }}$ position) yet, in teaching and learning in practice, it would seem to take much more significance ( $4^{\text {th }}$ position). In many schools, significant investment has been made in the provision for music technology and much of the working space of classrooms in several of the schools visited is taken up with computers and keyboards. It is to be presumed, therefore, that there is a natural desire to make use of that investment and equipment wherever possible, though not always with sufficient consideration of the most effective use of it to develop musical learning (Ofsted, 2012).

Aspects of musical competencies which would seem to have ranked highly in the sorting activity but less so in practice include improvising, singing, aural development and the ability to recognise the expressive content of music. One of the largest differences between the two rankings is in relation to singing, generally considered to be an important competency - ranked in $3^{\text {rd }}$ position. However, little singing was observed in lessons and, where it did take place, an OSS of no higher that '1' was awarded: little attempt was made to develop quality. Whilst just one lesson was observed of each participant, comments made in interviews also suggest that there is some reluctance to include singing activity with any emphasis on its development. For example, one participant admitted that he was not always 'fussy' enough about the quality of the singing. These findings would appear to reflect research by Ofsted (2012) who report that "singing was inadequate - or simply not happening at all - in 41 of the 90 schools inspected" (Ofsted, 2012: 31).

\section{Discussion: the place of developing musicianship in the secondary KS3 classroom}

In music, it is important to bear in mind that competencies are not items of knowledge which young people take 'on board' and learn in response to input opportunities provided by their teachers. They are, rather, attributes and characteristics which develop over time with appropriate opportunities in which the young people can immerse themselves in the sounds and their meanings and which form part of the activities in which they will participate (Spruce, 2012).

Composing - the activity of devising one's own original sound canvas - is a case in point in relation to its place in the music curriculum. The data presented in this paper suggests that it is an important competency for aspiring musicians and in 5 of the 11 lessons observed, composing and/or its related activity, improvising, took place. It is a core component within the NC (DfE, 2013) as well as many of the higher music examinations (GCSE, A-level). However, the mean OSS scores for these five lessons in composing and improvising together was 2.0 (evident in the lesson with a degree of significance but not fully observed, e.g. with little emphasis on development/improvement). It has been observed earlier that, 
of the survey participants, only a little over half reported having experience or expertise as composers and, without this, it is a challenge to help young people to develop the ability to any depth. This was evidenced in one lesson where the principal focus was on composing and in which the music came together with intentionally little teacher intervention and in a seemingly rather haphazard manner with little apparent appreciation of precisely how one can convey particular ideas through music. Composing music can also be time-consuming with ideas sometimes long in gestation and development. Where lessons are often one week apart and activities rarely being extended beyond four or five lessons, consistency and fluency of ideas can be a challenge for the young people.

There is almost unanimous acknowledgement that performing is an important musical competency - both on an instrument (ranked no.1) and singing (ranked no.3) and, indeed, performing on a musical instrument has been the most observed activity in this study (in 9 of the 11 observed lessons); and this activity also had the highest OSS score of 2.6. However, though singing was observed in 5 of the lessons, in none of them was the OSS score higher than 1 and in all cases the activity was quite short (less than 10 minutes). The difficulties seem to lay in three areas: (1) teacher confidence (Bannan, 2002); (2) the teachers' perception that children do not want to sing and that trying to force the issue can be counterproductive (evident in one lesson where the teacher, by his own admission, wanted the pupils to enjoy singing and did not wish to attempt to improve intonation); and (3) the choice of repertoire and the nature of teacher feedback (Welch, 2003). Compounding these issues concerning singing is that, even with instrumental performing, in many schools this is restricted to electric keyboard with pairs of students working together, sharing the instrument, and 'locked' inside headphones. In only one observed lesson was performing on a different instrument - guitar - genuinely acoustic. Performing was also largely restricted to using the instrument to learn to play a piece of music, getting the notes right and in time, but with little focus on developing technique or expression. At times the knowledge/expertise of the teacher was also 'tested', as in the case of the trainee teacher trying to support his pupils learning a melody on the keyboard when he had little skill on the keyboard himself, being an expert woodwind player. The sorting activity concerning 'Learning Contexts' demonstrates that 'performing with others' is a major influence on the development of musicianship, yet only in the guitar lesson did the pupils perform on instruments in groups larger than pairs. It is acknowledged that in composing activities, performing with others also takes place (as in the composing activity described in the previous paragraph), peforming the music the students have devised. As such, working in a group had a tendency to increase overall confidence and security, though it was also observed that the most confident students could also tend to dominate the decision-making and, indeed, the music-making process.

One of the contexts in which musicians develop that appeared to be challenging to facilitate was that of being able to practise regularly. Research participants ranked the learning context in $2^{\text {nd }}$ position in the 
sorting activity, yet limited evidence for this being allowed for in class music lessons was to be found in observations and interviews. Most on-going development of musical skills such as performing and composing can take considerable lengths of time (Harris \& Hawksley, 1989; Lehmann \& Gruber, 2006; Hallam, 2011). However, time is limited in many English secondary schools and timetabling has become an increasingly challenging issue for music over recent years (Ofsted, 2012) which can mitigate against the ability to enable, for example, regular and consistent practise opportunities, especially where young people have limited access to instruments outside school or the motivation to seek those opportunities. Even within single lessons, time management can be an issue with an average of $57 \%$ of each lesson observed as part of this study being devoted to the development of one or more musical competencies. In one lesson, focusing on 'songwriting', 15 minutes of the 50-minute lesson was devoted to the composing activity, the rest being made up of a study of models and performing work prepared in the lesson to the rest of the class. Students had little opportunity to 'get to grips' with the materials they were working with deeply enough before being interrupted.

\section{Conclusions and implications}

In considering the findings from this research study, it is possible to take the view that secondary music education today is aimed more at providing young people with a series of music-related experiences and that, if any were captivated by them, they might choose to undertake further musical studies beyond the classroom. There is an alternative view of the purpose of music education which is that it should contribute to the development of the next generation of musicians (from within the resources of class music alone). It is the contention here that these are not the same thing. It can also be argued that the former view (that classroom music presents a series of musical experiences) can be fully inclusive and 'attractive' to all young people but that the more musically orientated/gifted will wish to seek considerable, supplementary and potentially expensive (time, energy, finance), musical learning beyond the classroom. The latter view of music education (that it seeks to develop musicians) will take the assumption that all young people are musicians and have the capacity for deeper and broader musicality but that this may, potentially, be less 'attractive' to the less musically-minded pupil. If the aim of music education is geared more to musical experiences - as evidence from this research tends to suggest - then the criticisms by Ofsted (2012), in which there is a lack of musical progress in young people and of understanding of how teachers ensure progress, are hardly likely to be addressed within the classroom alone. As a consequence, significant numbers of young people in schools will not, therefore, make progress towards musicianship. The argument arising from this study is that this is due to a mis-match of expectations, knowledge and skills, and perceptions of what it is to be musical and how to develop musicianship, amongst some of the music educators employed by schools, music professionals, and 
policy makers in local and national government. Surely, the latter 'purpose statement - that of developing musicians and musicianship - is what many musicians become teachers to achieve.

Three implications arise: firstly, music should be given greater prominence in the education of all, rather than the select few. The tendency at present with, for example, the English Baccalaureate, is for it to be reduced, though this is far from being universal (Creech et al., 2015). The focus for new qualifications will need to include music, to move from STEM (Science, Technology, Engineering and Mathematics) to STEAM (including the addition of the Arts). Additionally, at key stage 3, some protection of the curriculum should be guaranteed (including in non-state maintained schools) to ensure that the place of music education is not eroded by shortening key stage 3 and through arts carousels that promote periodic 'visiting' of music by young people (Ofsted, 2012).

Secondly, music teachers should review their curricula to ensure that a focus on the development of musicianship is at the core of teaching and learning by directing attention to the development of musical competencies in their students and through the maximising of time spent in lessons on these. This may require covering fewer topics but over longer periods of time such that pupils can spend time in honing skills and focusing energies on the development and depth of competencies.

Thirdly and finally, courses in which musicians and potential school teachers engage at undergraduate level and in initial teacher education, should seek mechanisms for increasing time and focus on broadening subject knowledge, understanding and skills. A one-year PGCE programme, for example, is unlikely to be able to provide sufficient time for beginning teachers to develop these skills and knowledge as well as the other pedagogical and school-based experiential training needs (Durrant \& Laurence, 2010). It may be necessary to consider whether ITE programmes may need to be extended and/or whether undergraduate music courses should include more teaching-based modules as well as scope for developing the wider skill set necessary for teaching.

If music is for all and all young people have the potential for musicality, then factors such as teacher education, the nature of the learning experience and the musical needs of young people should become the focus for policy development (at local and national level), the training of teachers, and the educational partnerships which can contribute to the music education of all. In this way, young people will more likely attain their potential as musicians and music learning in the classroom will make a significant contribution to this (Dalladay, 2014). 


\section{References}

BANNAN, N. (2002) Developing vocal skills in the secondary classroom. In G. Spruce (Ed.) Aspects of teaching secondary music: perspectives on practice (pp. 106-120). London: Routledge Falmer.

BEN-TOVIM, A. (1979) Children and music. London: A\&C Black.

BIBBY, H. (2013) The problems of school music: self-efficacy and musical identities in years 7, 8 and 9. In J. Finney \& F. Laurence (Eds.) Masterclass in music education: transforming teaching and learning (pp. 139-150). London: Bloomsbury Publishing Plc.

BORTHWICK, S.J. \& DAVIDSON, J.W. (2012) Developing a child's identity as a musician: a family 'script' perspective. In R. Macdonald, D. Hargreaves \& D. Miell, D. (Eds.) Musical identities (pp. 60-78). Oxford: Oxford University Press.

BRAY, D. (2000) An examination of GCSE music uptake rates. British Journal of Music Education, 17: 1, 79-89.

BRYMAN, A. (2012) Social research methods. Oxford: Oxford University Press

CLARKE, E., DIBBEN, N. \& PITTS, S. (2010) Music and mind in everyday life. Oxford: Oxford University Press.

COOKE, C., EVANS, K., PHILPOTT, C. \& SPRUCE, G. (2016) Learning to teach music in the secondary school. Abingdon: Routledge

CREECH, A., SAUNDERS, J. \& WELCH, G. (2015) Musical pride: music education in plural communities (draft report). London: University College London, Institute of Education; for 'The Mix', Luton, Slough.

CROSS, I. (2006) Music and social being. Musicology Australia, 28, 114-126.

DALLADAY, C. (2014) The biography of music teachers, their understanding of musicality and the implications for secondary music education. Unpublished PhD Thesis: University of East London.

DEPARTMENT FOR EDUCATION (DfE) (2011) The importance of music: a national plan for music education. London: Department for Education.

DEPARTMENT FOR EDUCATION (DfE) (2013) The National Curriculum in England: framework document. London: Department for Education.

DURRANT, C. \& LAURENCE, K. (2010) The initial and ongoing education of music teachers. In S. Hallam, \& A. Creech (Eds.) Music education in the $21^{\text {st }}$ century in the United Kingdom (pp. 176-191). London: Institute of Education, University of London.

FLETCHER, P. (1989) Education and music. Oxford: Oxford University Press.

GREEN, L. (2002) How popular musicians learn. Aldershot: Ashgate.

GREEN, L. (2008) Music, informal learning and the school: a new classroom pedagogy. Aldershot: Ashgate.

HALLAM, S. (2006) Music psychology in education. London: Institute of Education, University of London

HALLAM, S. (2011) Culture, musicality and musical expertise. In M.S. Barrett (Ed.) A cultural psychology of music education (pp. 201-224). Oxford: Oxford University Press.

HARGREAVES, D.J. (1986) The developmental psychology of music. Cambridge: Cambridge University Press.

HARGREAVES, D., MIELL, D. \& MACDONALD, R. (2002) What are musical identities, and why are they important? In R. Macdonald, D. Hargreaves \& D. Miell (Eds.) Musical identities (pp. 1-20). Oxford: Oxford University Press.

HARRIS, R. \& HAWKSLEY, E. (1989) Composing in the classroom. Cambridge: Cambridge University Press. 
HARRISON, C. \& MCCULLOUGH, L. (Eds.) (2011) Musical pathways. Solihull: National Association of Music Educators (NAME).

JAFFURS, S. (2004) Developing musicality: formal and informal practices. Action, Criticism, and Theory for Music Education, 3: 3 (December 2004). http://act.maydaygroup.org/articles/Jaffurs3 3.pdf (Retrieved 15/10/2013).

KEMP, A. (1996) The musical temperament. Oxford: Oxford University Press.

LAMONT, A. (2002) Musical identities and the school environment. In R. Macdonald, D. Hargreaves \& D. Miell, D. (Eds.) Musical identities (pp. 41-59). Oxford: Oxford University Press.

LEHMANN, A.C. \& GRUBER, H. (2006) Music. In K. Ericsson, N. Charness, P. Feltovich \& R. Hoffman (Eds.) The Cambridge handbook of expertise and expert performance (pp. 457-470).

Cambridge: Cambridge University Press.

MCPHERSON, G., DAVIDSON, J. \& FAULKENER, R.F. (2012) Music in our lives. Oxford: Oxford University Press.

MILLS, J. (2005) Music in the school. Oxford: Oxford University Press.

MÜLLENSIEFEN, D., GINGRAS, B. \& STEWART, L. (2011) How musical are you? http://www.bbc.co.uk/labuk/articles/musicality/ (Retrieved 30/03/2011, page since removed).

OFFICE FOR STANDARDS IN EDUCATION (Ofsted) (2012) Music in schools: wider still, and wider; quality and inequality in music education 2008-11. London: Ofsted. Available for download at http://www.ofsted.go.uk

PAYNTER, J. (1982) Music in the secondary school curriculum. Cambridge: Cambridge University Press.

PAYNTER, J. (1994) The composer as educator: things that matter. In H-W. Heister, K. Hesiter-Grech, \& G. Scheidt (Eds.) Zwischen Aufklärung und Kulturindustrie/Festschrift für Georg Knepler zum 85 Gerburtstag. III Music/Gesellchaft, Hamburg, von Bockel Verlag; p.45-54.

PFLEDERER, M. (1963) The nature of musicality. Music Educators Journal. 49: 6, 49-52.

ROGERS, R. (2002) Creating a land with music: the work, education and training of professional musicians in the $21^{\text {st }}$ century. London: Youth Music.

SAUNDERS, J. (2008) The music classroom: pupils' experience and engagement during adolescence. Unpublished PhD Thesis: Institute of Education, University of London.

SAUNDERS, J. \& WELCH, G. (2012) Communities of music education: a pilot study. London: Institute of Education, University of London.

SAVAGE, J. (Ed.) (2013) The guided reader to teaching and learning music. Abingdon: Routledge.

SPRUCE, G. (2012) Musical knowledge, critical consciousness and critical thinking. In C. Philpott \& G. Spruce (Eds.) Debates in music teaching (pp. 185-196). London: Routledge.

SPRUCE, G. \& MATTHEWS, F. (2012) Musical ideologies, practices and pedagogies. In C. Philpott \& G. Spruce (Eds.) Debates in music teaching (pp. 118-134). London: Routledge.

WELCH, G. (2001) The misunderstanding of music: inaugural lecture. London: Institute of Education, University of London.

WELCH, G. (2003) The importance of singing. In A. Paterson \& E. Bentley (Eds.) Bluebirds and crows: developing a singing culture in and out of school (pp. 2-5). Matlock: National Association of Music Educators (NAME).

WELCH, G. (2006) Singing and vocal development. In G. McPherson (Ed.) The child as musician (pp. 311-329). Oxford: Oxford University Press. 
WELCH, G. (2012) Musical creativity, biography, genre and learning. In D.J. Hargreaves, D.E. Miell \& R.A.R. Macdonald (Eds.) Musical imaginations: multidisciplinary perspectives on creativity, performance and perception (pp. 385-398). Oxford: Oxford University Press.

WELCH, G. et al. (2008) Investigating musical performance (IMP): comparative studies in advanced musical learning. Swindon: Economics and Social Research Council.

WELCH, G., PURVES, R., HARGREAVES, D. \& MARSHALL, N. (2010) Reflections on the 'Teacher Identities in Music Education [TIME] Project'. Action, Criticism \& Theory for Music Education, 9 (2), 11-32. http://act.maydaygroup.org/articles/Welch9_2.pdf (Retrieved 02/10/2016).

WRIGHT, R. (2012) Policy and practice in music education: a sociological perspective. In C. Philpott \& G. Spruce (Eds.) Debates in music teaching (pp. 20-32). London: Routledge.

YORK, N. (2001) Valuing school music: a report on school music. University of Westminster \& Rockschool Ltd. 